\title{
Pierre de L'Estoile, Journal du règne de Henri IV
}

\section{Michele Mastroianni}

\section{(2) OpenEdition}

\section{Journals}

\section{Edizione digitale}

URL: http://journals.openedition.org/studifrancesi/4340

DOI: $10.4000 /$ studifrancesi. 4340

ISSN: 2421-5856

\section{Editore}

Rosenberg \& Sellier

\section{Edizione cartacea}

Data di pubblicazione: 1 settembre 2016

Paginazione: 319

ISSN: 0039-2944

\section{Notizia bibliografica digitale}

Michele Mastroianni, «Pierre de L'Estoile, Journal du règne de Henri IV », Studi Francesi [Online], 179 (LX

II) | 2016, online dal 01 septembre 2016, consultato il 18 septembre 2020. URL : http://

journals.openedition.org/studifrancesi/4340; DOI : https://doi.org/10.4000/studifrancesi.4340

\section{Questo documento è stato generato automaticamente il 18 settembre 2020.}

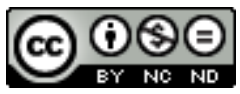

Studi Francesi è distribuita con Licenza Creative Commons Attribuzione - Non commerciale - Non opere derivate 4.0 Internazionale. 


\title{
Pierre de L'Estoile, Journal du règne de Henri IV
}

\author{
Michele Mastroianni
}

\section{NOTIZIA}

PIERRE DE L'ESTOILE, Journal du règne de Henri IV, édition critique publiée sous la direction de Gilbert Schrenck, Tome II: 1592-1594, édité par Xavier Le Person, glossaire établi par Volker Mecking, Genève, Droz, 2014, «Textes Littéraires Français» 630, xxIV-551 pp.

1 Dopo il primo volume dell'ottima e utilissima edizione del Journal du règne de Henri IV di Pierre de L'Estoile avviata da G. Schrenck (cfr. questi «Studi», 165, 2011, pp. 631-632), compare ora un secondo volume (come per il primo l'edizione è a cura di X. Le Person) che copre gli anni 1592-1594 - anni tormentatissimi in cui Parigi è nelle mani dei ligueurs - fino all'ingresso, dopo un lunghissimo assedio, di Enrico IV nella capitale che gli apre le porte riconoscendolo come re legittimo dopo cinque anni dal suo avvento alla corona. Siamo in presenza di una fonte di informazioni di prima mano, da parte di un testimone che vivendo nella Parigi della Ligue permette di ricostruire l'atmosfera della capitale di quegli anni. Anzitutto, abbiamo una ricostruzione del mondo degli antinavarristi, soprattutto per quanto riguarda il clero ligueur: per esempio, interessante è il quadro della predicazione nelle parrocchie, ove i curati trasformano i loro sermoni in attacchi di incredibile violenza (fino ad esortare, come fa il notissimo Boucher, al regicidio). Queste prediche sono riferite con precisione da L'Estoile, che dichiara di avere «pris plaisir» subito dopo la messa «de faire le present extrait» del «venerable sermon» appena ascoltato. Così pure questa parte del Journal dà informazioni preziose sugli Stati Generali della Ligue, convocati all'inizio del 1593 per eleggere un nuovo re. Viene così offerto un quadro interessantissimo del gioco delle candidature e delle manovre politiche del duca di Mayenne, a capo del partito contrario a Enrico IV. L'Estoile è anche molto abile, con una scrittura piena di ironia, a rappresentare la rete dei compromessi, degli opportunismi, dei passaggi da un partito all'altro. Oltre all'eccellenza filologica di questa edizione, puntualmente annotata, 
segnaliamo, come già per il primo volume, l'analisi del lessico e il glossario a cura di V. Mecking: si tratta di strumenti per gli storici della lingua che vanno ben al di là dei soliti repertori linguistici. 